\title{
Detection of Fungi in Cooling Tower Samples Using Fluorescent In Situ Hybridization and Traditional Culture- Dependent Methods
}

\author{
Duygu GÖKSAY KADAIFÇILEER*, Zuhal ZEYBEK
}

Istanbul University, Faculty of Science, Department of Biology, Fatih / Istanbul, Turkey

\begin{abstract}
The determination of the presence of Eurotiales members, which are widely distributed in nature and in man-made aquatic systems, is important for taking measures against those capable of creating opportunistic infections and allergies. In this study, the presence of fungi in cooling-tower samples was determined by using two different methods, one being fluorescent in situ hybridization (FISH), the second culturing; both sets of results were compared with each other. For this purpose, a total of 40 water and biofilm samples were taken from different cooling towers in Istanbul for investigation. In the culture method, all samples were applied to the isolation medium after pretreatment. The results of the applications were evaluated after 14 days. With the FISH method, all samples were fixed and hybridized by using suitable probes and were investigated under an epifluorescent microscope. Results were obtained after a short period of three days. The FISH method was able to detect $100 \%$ of fungi in all samples, whereas the culture method was able to detect $97.5 \%$ of the fungi in the samples. With culture method, the most isolated fungi were from the Aspergillus and Penicillium genera. As a result of the study, both methods are recommended to be used in conjunction.
\end{abstract}

Key words: Aspergillus, culture-independent method, Eurotiales, fluorescent in situ hybridization

\section{Floresanlı Yerinde Hibritleme ve Geleneksel Kültür Yöntemlerini Kullanılarak Soğutma Kulesi Örneklerinde Fungusların Tespiti}

Öz: Doğada ve insan yapımı su sistemlerinde yaygın olarak bulunan Eurotiales üyesi fungusların varlığının tespiti, fırsatçı enfeksiyon ve alerjilere yol açabilen bu funguslara karşı alınabilecek önlemler açısından önemlidir. Bu çalışmada soğutma kulesi örneklerindeki fungusların varlığı, hem floresanlı yerinde hibritleme (FISH) hem de kültür yöntemiyle araştırılmış, her iki yöntemin sonuçları karşılaştırılmıştır. Bu amaçla İstanbul'daki farklı soğutma kulelerine ait toplam 40 adet su ve biyofilm örnekleri alınarak incelenmiştir. Kültür yönteminde tüm örnekler, ön işlemlerden sonra izolasyon besiyerine ekilmiştir. Ekimlerin sonuçları 14 gün sonunda değerlendirilmiştir. FISH yönteminde ise; tüm örnekler fikse edilip uygun problar kullanılarak hibridizasyonu yapıldıktan sonra epifloresan mikroskopta incelenmiştir. FISH yöntemi ile 3 gün gibi kısa bir sürede sonuç elde edilmiştir. Ayrıca bu yöntem ile incelenen örneklerin tamamında, kültür yönteminde ise incelenen örneklerin \%97.5'in de fungus tespit edilmiştir. Kültür yöntemi ile en çok izole edilen fungusların Aspergillus ve Penicillium cinsine ait oldukları belirlenmiştir. Çalışma sonucunda her iki yöntemin beraber kullanılması önerilmektedir.

Anahtar kelimeler: Aspergillus, kültür bağımsız yöntem, Eurotiales, floresanlı yerinde hibritleme

* corresponding author: dgoksay@istanbul.edu.tr 


\section{Introduction}

Fungi, which are usually saprophytes, break up the organic substances they grow on and turn them into inorganic materials, readying them for consumption by other organisms. Therefore, they play an important role in organic pollutant removal and mud refining. In contrast, as microbial polluting sources of aquatic systems, fungi may also pose a health risk for eukaryotic organisms (humans, plants, and animals). Apart from plant pathogens, numerous respiratory opportunistic pathogenic fungi belong to the phylum Ascomycota, of which Aspergillus and Penicillium are the dominant genera of the order Eurotiales (Öner, 1998; Guarro et al., 1999). In fact, the microfungi most commonly obtained in soil and water studies in Turkey belong to the genus Aspergillus (Asan \& Ekmekçi, 2002; Asan et al., 2003; Asan et al., 2004; Yazıcıoğlu et al., 2004; Rasime et al. 2005; Ilhan et al. 2006; Göksay Kadaifciler \& Demirel, 2017). This genus, which is widely found around the world, exhibits high reproduction rates and capacities. Its atmospherically dispersed conidia are suspended in the air and can be transported anywhere with dust and other particles (Kantarcıoğlu \& Yücel, 2003). The infections and/or disease caused by Aspergillus spp. are mainly linked to the lungs. Due to the inhalation of Aspergillus spores, bronchial asthma can occur in people who are allergic to the antigens of this fungus. In addition, this genus' members may become invasive, and they can migrate to the subcutaneous tissue, the central nervous system, the lungs, and the endocardium in immunocompromised persons (Szymanska 2005). Cooling towers represent a favorable environment for microbial growth because of the presence of water, nutrients, various temperatures, and $\mathrm{pH}$ ranges, and microorganisms can be easily dispersed by aerosols formed by the system (Choudhary, 1998). In cooling tower samples, fast detection and identification of fungi, which can cause potentially allergenic and toxicogenic reactions, is of great importance.

Fluorescent in situ hybridization (FISH) is a technique that enables the monitoring of threedimensional distributions of target molecules in the cell using epifluorescent or confocal laser microscopy due to the hybridization of nucleic acids with specific sequences in the cell; this can be done using fluorescence-stained oligonucleotides (probes) without damaging microorganisms' cells. In contrast to the classical culture method, using FISH, it is possible to detect microorganisms in their environment and assess their physiological activities, morphology, and position with respect to each other; it is also possible to determine their numbers by means of FISH. In addition, the method is helpful for the detection of microorganisms with unknown specific culture conditions (Amann et al., 1995; Amann et al., 2001). For this reason, taking into consideration the approaches' advantages and disadvantages, this study aims to use FISH (a culture-independent method) and the traditional culture-dependent method to investigate members of Eurotiales, especially Aspergillus, in cooling tower samples.

\section{Materials and Methods}

A total of 20 water and 20 biofilm samples were collected from 20 cooling towers associated with 13 buildings in the city of Istanbul, Turkey.

\section{The Culture-Dependent Method}

Water samples were concentrated by filtration through nitrocellulose filters with a pore size of $0.45 \mu \mathrm{m}$. Sabouraud dextrose agar (SDA) plates containing the antibiotic and Rose Bengal stain were used for isolation of fungi (Arvanitidou et al., 1999; Asan et al. 2003). Filters were placed on the SDA plates, and biofilm samples were scraped from the tower inside surfaces (10 $\mathrm{cm}^{2}$ ) using a sterile cotton swab and suspended in $20 \mathrm{~mL}$ of sterile tap water (Gagnon \& Slawson, 1999). Biofilm samples were serially diluted, and diluted 1-mL samples were spread plated onto SDA plates. All SDA plates were incubated at $25^{\circ} \mathrm{C}$ for 30 days. After incubation, the fungal colonies and fungal colony mean were calculated. Following this, the colonies were subcultured on malt extract agar slants and stored at $+4^{\circ} \mathrm{C}$. 
Fungal isolates were inoculated onto malt extract agar and potato dextrose agar for morphological identification. Plates were incubated for $7-14$ days at $25^{\circ} \mathrm{C}$. At the end of the incubation period, the colonies' macroscopic and microscopic characteristics were examined using a stereomicroscope and light microscope, respectively. Following generally accepted standards, lactophenol cotton blue was used as the mounting medium to identify the genus levels (Barnett \& Hunter, 1999; Ellis, 1971; Sime \& Abbott, 2002).

\section{Fluorescent in Situ Hybridization} (Culture-Independent Method)

Water samples were concentrated by filtration through nylon filters with a pore size of $0.22 \mu \mathrm{m}$; the filters were then suspended in 10 $\mathrm{mL}$ of sterile tap water. After homogenate preparation, sample-50\% ethanol mixes (1:1, $\mathrm{v} / \mathrm{v}$ ) were stored at $-20^{\circ} \mathrm{C}$ and fixed within 2 days. Biofilm samples were scraped from tower inside surfaces $\left(10 \mathrm{~cm}^{2}\right)$ using a sterile cotton swab and suspended in $10 \mathrm{~mL}$ of sterile tap water. After they were homogenized, samples were stored as mentioned above. The fixation of both water and biofilm samples was carried out with $4 \%$ paraformaldehyde (PFA) overnight at $4^{\circ} \mathrm{C}$ (Gagnon \& Slawson, 1999; Kasapgil İnce et al.,2006). The hybridization method was modified based on Kasaplıgil Ince et al.'s (2006) study. After the fixation, PFA was centrifuged three times with $1 \times$ phosphate-buffered saline for cleaning, and the washing was performed at $5000 \mathrm{~g}$. At the end of the washing step, the $10-\mu \mathrm{l}$ fixed samples were placed in wells on covered polytetrafluoroethylene microscopic slides and allowed to dry. Drying slides were sequentially passed through $50 \%, 80 \%$, and $96 \%$ alcohol series for $3 \mathrm{~min}$ at $48^{\circ} \mathrm{C}$. A $1-\mu \mathrm{l}$ probe $(50 \mathrm{ng} / \mu \mathrm{l})$ and hybridization buffer $(10 \mu \mathrm{l})$ containing $0.9 \mathrm{M}$ $\mathrm{NaCl}, 20 \mathrm{mM}$ Tris $/ \mathrm{HCl}, 0.01 \%$ (w/v) sodium dodecyl sulfate, and $30 \% \mathrm{v} / \mathrm{v}$ formamide were added to the slide wells in the moist hybridization chamber and left overnight at $48^{\circ} \mathrm{C}$ for hybridization in the dark; following this, $2 \mu \mathrm{l}$ of DNA binding dye-6-diamidino-2-phenylindole (DAPI) was added to the wells and incubated for $30 \mathrm{~min}$ in the dark. At the end of this time, the slides were washed using wash buffer containing $160 \mathrm{mM} \mathrm{NaCl}, 20 \mathrm{mM}$ Tris/ $\mathrm{HCl}, 5 \mathrm{mM}$ Ethylenediaminetetraacetic acid (EDTA), and $0.01 \%(\mathrm{w} / \mathrm{v})$ sodium dodecyl sulfate for $15 \mathrm{~min}$ at $48^{\circ} \mathrm{C}$ before a final 10 -min wash with bidistilled water at $4^{\circ} \mathrm{C}$. Following this, $5 \mu \mathrm{l}$ of Citifluor antifadent agent was added to the dried slides to prevent rapid fading of the dyes. The dried slides were examined under a Nikon Eclipse 80i epifluorescent microscope and photographed. All samples were analyzed in duplicate.

Aspergillus fumigatus ATCC 10894 was used for the positive control fungus, and preliminary experiments were also carried out with this fungus. One well containing the EUK516 probe was used for positive control for eukaryotes. One well containing no probes and hybridization buffer without microorganisms and one well containing the NON338 probe were used for negative controls (Table 1 ).

\section{Results}

According to the culture method results, fungi were detected in 39 of 40 (97.5\%) examined water and biofilm samples. In only one biofilm sample could no fungi be identified. The minimum and maximum values of the fungal colony counts were 4 and 1200 colonies $/ 100 \mathrm{~mL}$ in water samples and 0.1 and 40 colonies $/ \mathrm{cm}^{2}$ in biofilm samples, respectively (Table 2 ). The most frequently identified fungi were Aspergillus, Penicillium, and Cladosporium (Figure 1). Aspergillus spp. were isolated from all cooling towers.

According to the FISH method results, fungi were detected in all water and biofilm samples (total 40 samples). The fungal probes' signal results are given in Table 2 . 
Table 1. General characteristics of rRNA-targeted oligonucleotide probes and fluorescent dyes

\begin{tabular}{|c|c|c|c|c|}
\hline Probe name & $\begin{array}{l}\text { Probe } \\
\text { sequencing } \\
5 '-3 \text { ' }\end{array}$ & $\begin{array}{l}\text { Target } \\
\text { group/specificity }\end{array}$ & Dye/color & Usage \\
\hline EUK516 & $\begin{array}{l}\text { '-ACC AGA } \\
\text { CTT GCC CTC } \\
\text { C-3' }\end{array}$ & 18S rRNA/Eukaryotes & 5'-CY3 (red) & Positive control \\
\hline EUROT1108 & $\begin{array}{lr}\text { 5'-TTT } & \text { AAG } \\
\text { GGC } & \text { CGA } \\
\text { GGT CTC-3' }\end{array}$ & 18S rRNA/Eurotiales & $\begin{array}{l}\text { 5'-FAM } \\
\text { (green) }\end{array}$ & Eurotiales \\
\hline NON338 & $\begin{array}{ll}\text { 5'-ACT }^{\prime} \text { CCT } \\
\text { ACG } & \text { GGA } \\
\text { GGC AGC-3' }\end{array}$ & No sense/No target & $\begin{array}{l}\text { 5'-FAM } \\
\text { (green) }\end{array}$ & $\begin{array}{l}\text { Negative } \\
\text { control }\end{array}$ \\
\hline DAPI & - & $\begin{array}{l}\text { DNA binding dye } \\
\text { (All DNA) }\end{array}$ & Blue & $\begin{array}{l}\text { to determine } \\
\text { the number of } \\
\text { nuclei and to } \\
\text { assess gross } \\
\text { cell } \\
\text { morphology }\end{array}$ \\
\hline
\end{tabular}

Table 2. Results of culture-dependent and fluorescent in situ hybridization methods

(Colony $/ 100 \mathrm{~mL}$ : colony per $100 \mathrm{~mL}$; Colony $/ \mathrm{cm}^{2}$ : colony per square centimeter; +: fungal probes' signal detected)

\begin{tabular}{|c|c|c|c|c|c|c|c|}
\hline \multicolumn{4}{|c|}{ Culture method } & \multicolumn{2}{c|}{ Fluorescent in situ hybridization method } \\
\hline $\begin{array}{c}\text { Water } \\
\text { samples } \\
\text { (Code) }\end{array}$ & $\begin{array}{c}\text { Colonyl } \\
\text { 100mL }\end{array}$ & $\begin{array}{c}\text { Biofilm } \\
\text { samples } \\
\text { (Code) }\end{array}$ & Colony/cm & $\begin{array}{c}\text { Water } \\
\text { samples } \\
\text { (Code) }\end{array}$ & $\begin{array}{c}\text { Signal } \\
\text { results }\end{array}$ & $\begin{array}{c}\text { Biofilm } \\
\text { samples } \\
\text { (Code) }\end{array}$ & $\begin{array}{c}\text { Signal } \\
\text { results }\end{array}$ \\
\hline W1 & 15 & B1 & 1 & W1 & + & B1 & + \\
\hline W2 & 400 & B2 & 1 & W2 & + & B2 & + \\
\hline W3 & 550 & B3 & 2.3 & W3 & + & B3 & + \\
\hline W4 & 120 & B4 & 40 & W4 & + & B4 & + \\
\hline W5 & 333 & B5 & 0 & W5 & + & B5 & + \\
\hline W6 & 11 & B6 & 0.2 & W6 & + & B6 & + \\
\hline W7 & 17 & B7 & 0.1 & W7 & + & B7 & + \\
\hline W8 & 11 & B8 & 1 & W8 & + & B8 & + \\
\hline W9 & 9 & B9 & 0.1 & W9 & + & B9 & + \\
\hline W10 & 4 & B10 & 0.6 & W10 & + & B10 & + \\
\hline W11 & 6 & B11 & 0.1 & W11 & + & B11 & + \\
\hline W12 & 12 & B12 & 0.1 & W12 & + & B12 & + \\
\hline W13 & 7 & B13 & 0.2 & W13 & + & B13 & + \\
\hline W14 & 110 & B14 & 6.4 & W14 & + & B14 & + \\
\hline W15 & 1200 & B15 & 0.1 & W15 & + & B15 & + \\
\hline W16 & 15 & B16 & 0.9 & W16 & + & B16 & + \\
\hline W17 & 30 & B17 & 2.2 & W17 & + & B17 & + \\
\hline W18 & 10 & B18 & 0.6 & W18 & + & B18 & + \\
\hline W19 & 13 & B19 & 0.1 & W19 & + & B19 & + \\
\hline W20 & 14 & B20 & 0.2 & W20 & + & B20 & + \\
\hline
\end{tabular}


As Fig. 2 shows, fungal spores determined with the EUROT1108 probe labeled with 5'-FAM were green, while EUK516 labeled with 5'-CY3 yielded a red color and DAPI yielded blue. The morphological structures of Aspergillus are shown in Figure 3.

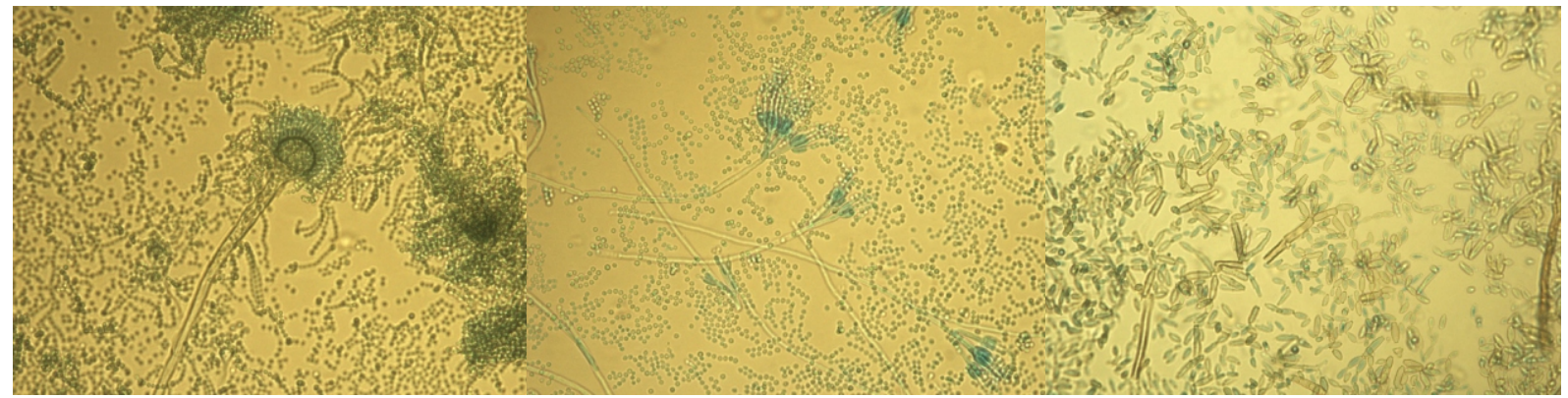

a

b

C

Figure 1. Morphologically identified fungus: (a) Aspergillus, (b) Penicillium, and (c) Cladosporium (x 500 magnification)

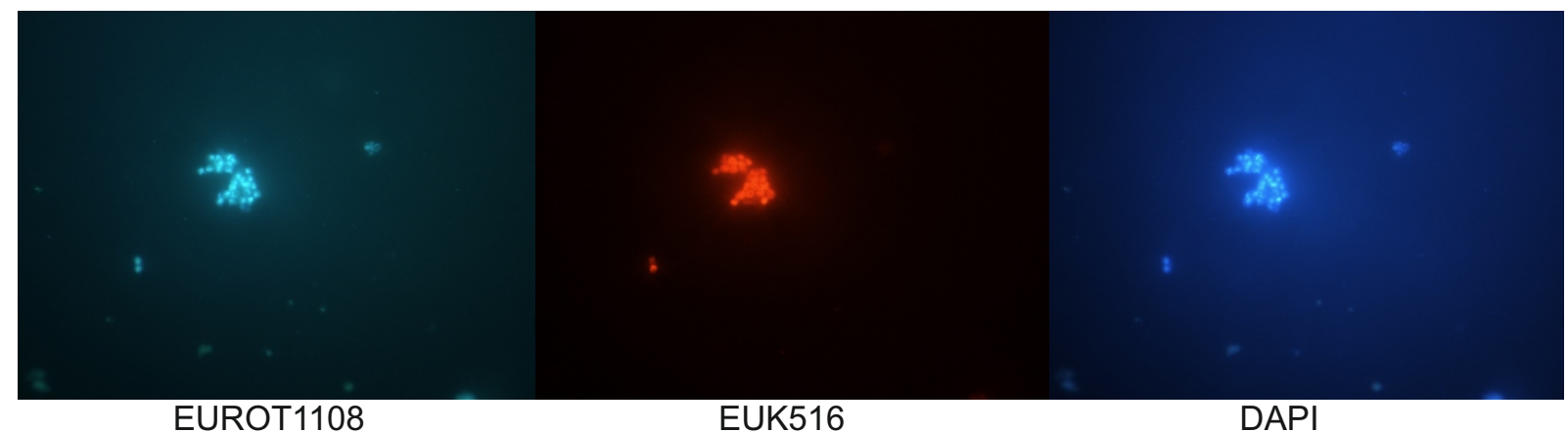

Figure 2. Fluorescent-labeled fungal spores (x 500 magnification)

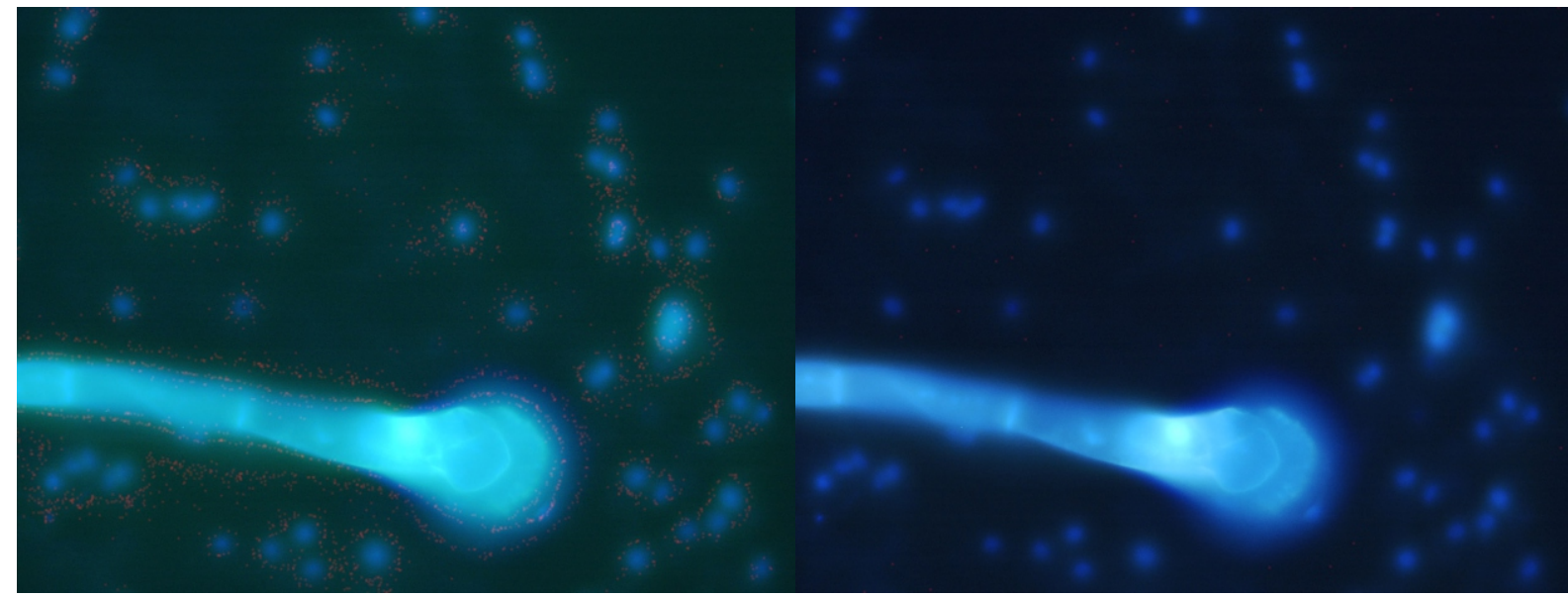

EUROT1108

DAPI

Figure 3. The structures of Aspergillus (x 500 magnification) 


\section{Discussion}

Cooling towers are suitable environments for many microorganisms and fungi to growth. However, the proliferation of these microorganisms may have unfavorable effects in terms of both clogging the systems and causing respiratory infections in humans due to the inhaling of aerosols. Therefore, it is important to determine the amounts of fungi in both water and biofilm samples of cooling towers. In this study, the comparison between the culture and FISH methods showed that the results were in accordance in terms of monitoring the presence of fungi in cooling towers. The advantage of the culture method is that it is possible to count the colonies, isolates can be obtained, and these isolates can be used in forthcoming studies. However, this technique takes a long time and requires great expertise, especially for specieslevel diagnostics. Moreover, this culture method is insufficient if the microorganisms are in viable but nonculturable (VBNC) form. At present, there are publications available on aquatic fungi, and especially zoosporic fungi, that cannot be cultured in freshwater media, and the importance of establishing a method in which these fungi can be cultured has been stressed (Baschien et al., 2008; Jobard et al., 2010). In the present study, fungi could be detected in all samples from cooling towers using the FISH method, whereas the culture method only allowed fungi to be detected in $97.5 \%$ of the examined samples. The probable reason for this is that the fungi in the biofilm sample were in the VBNC phase. The application of FISH can overcome this disadvantage. There is a need for further work to support these results.

Numerous studies have been performed in ecology, food science, agriculture, and human and veterinary medicine using the FISH method. Studies concerning fungi (e.g., Candida, Paracoccidioides, and Aureobasidium pullulans) have focused on medical and vegetable pathogenesis (Lischewsk et al., 1996; Li et al., 1997; Spear et al., 1999; Moter \& Göbel, 2000; Domingos Arantes et al., 2017). In fact, FISH is a novel technique in the determination of fungi, and it was first used in an environmental study with acidic mining drainages (Baker et al., 2004). This is the first study to detect fungi in cooling towers in Turkey using this method.

The most important advantage of FISH is that the presence of fungi can be determined in a much shorter amount of time than it can in the culture method. The faster the identification of pathogenic or opportunistic pathogenic fungi is, the easier it will be to determine the risk and mitigate it through appropriate measures (Moter \& Göbel, 2000; Amann et al., 2001). This will allow a disinfection process to be initiated in a cooling tower at risk of developing colonies of fungi. As a solution, suitable antifungals can be applied for the disinfection of cooling tower systems. Despite the advantages mentioned above, identification of mold is usually performed at the family and/or order level in the FISH method. This approach can be used to analyze microbial communities and detect the phylogenetic relationships among microorganisms. In our study, the EUROT1108 probe was used because of its specificity for Eurotiales. At present, species-specific probes exist for only the most recognized pathogenic yeasts. Development of molecular-based studies, such as fungal genome sequencing studies, will make it possible to produce probes that can identify fungi at the species level. Such advancements could be especially helpful in microbial ecology and biodiversity studies (Moter \& Göbel, 2000). In the present study, there are no quantitative results that can be compared with the culture method results. This is because the colonies formed from these fungi may arise from multiple spores or micelles, preventing accurate counting. 
In addition, probes may fade rapidly during investigation, meaning that no signals would be produced. For this purpose, it is recommended that investigation and sampling be carried out rapidly when multiple samples are present. Moreover, as shown in Figure 1, a portion of spores measured with EUK516 lost their luminescence during photographing.

Because of the negative effect of opportunistic fungal pathogens on public health, more studies using culture and cultureindependent techniques are needed to further the understanding of the distribution of these microorganisms in aquatic systems, and applying solutions like disinfection. In light of the information presented here, FISH could be used to complement the culture method and thus obtain more comprehensive information.

\section{Acknowledgements}

This work was supported by the "Scientific Research Projects Coordination Unit of Istanbul University" (project number 2435).

\section{References}

Amann, R.I., Fuchs, B., Behrens, S., The Identification of Microorganisms by Fluorescence In Situ Hybridisation, Current opnion in Biotechnology, 12(3): 231-236 (2001).

Amann, R.I., Ludwig, W., Schleifer. K.H., Phylogenetic Identification and In Situ Detection of Individual Microbial Cells without Cultivation. Microbiological Reviews. 59: 143-169 (1995).

Arvanitidou, M., Kanellou, K., Constantinides, T.C., Katsouyannopoulos, V., The Occurrence of Fungi in Hospital and Community Potable Waters, Letters in Applied Microbiology, 29: $81-84$ (1999).

Asan, A., Ekmekçi, S., Contribution to the Colonical and Morphological Characteristics of Some Aspergillus Species Isolated from Soil, Ege University Journal of The Faculty of Science, 25(1): 121-139 (2002).

Asan, A., Kırgız, T., Şen, B., Çamur-Elipek, B., Güner, U., Güher, H. :Isolation, Identification and seasonal distribution of airborne and waterborne fungi in Terkos lake (İstanbul-Turkey), Journal of Basic Microbiology, 43(2): 83-95 (2003).

Asan, A., İlhan, S., Şen, B., Potoğlu Erkara, İ., Filik, C., Çabuk, A., Demirel, R., Türe, M., Sarıca Ökten, S., Tokur, S.,: Airborne Fungi and Actinomycetes Concentrations in the Air of Eskişehir City (Turkey), Indoor and Built Environment, 13: 63-74 (2004).

Baker, B.J., Lutz, M.A., Dawson, S.C., Bond, P.L., Banfield, J.F., Metabolically Active Eukaryotic Communities in Extremely Acidic Mine Drainage, 70(10): 6264-6271 (2004).

Baschien, C., Manz, W., Neu,T.R., Marvanova', L., Szewzyk, U., In Situ Detection of Freshwater Fungi in an Alpine Stream by New Taxon-Specific Fluorescence In Situ Hybridization Probes, Applied and Cooling tower Microbiology, 74(20): 6427-6436 (2008).

Choudhary, S.G., Emerging Microbial Control Issues in Cooling Water Systems. Hydrocarbon Processing, 77(5): 91-102 (1998).

Demirel, R., Ilhan, S., Asan, A., Kınacı, E., Oner, S., Microfungi in Cultivated Fields in Eskişehir Provience (Turkey), Journal of Basic Microbiology, 45(4): 279-293 (2005).

Domingos Arantes, T., Cordeiro Theodoro R., de Melo Teixeira, M., Bagagli, E., Use of Fluorescent Oligonucleotide Probes for Differentiation between Paracoccidioides brasiliensis and Paracoccidioides lutzii in Yeast and Mycelial Phase, The Memórias do Instituto Oswaldo Cruz, Rio de Janeiro, 112(2): 140-145 (2017). 
Ellis, M.B., Dematiaceous Hyphomycetes, The Eastern Press, London, UK, (1971).

Gagnon, G.A., Slawson, R,M., An Efficient Biofilm Removal Method for Bacterial Cells Exposed to Drinking Water, Journal of Microbiological Methods, 34(3): 203- 214 (1999).

Göksay Kadaifciler, D., Demirel, R., Fungal Biodiversity and Mycotoxigenic Fungi in Cooling-Tower Water Systems in Istanbul, Turkey, DOI: 10.2166/wh.2017.274 (2017).

Guarro, J., Gene, J., Stchigel, A., Developments in Fungal Taxonomy, Clinical Microbiology Reviews, 12(3): 454500 (1999).

H.L. Barnett, B.B. Hunter, Illustrated genera of imperfect fungi, APS Press, St. Paul-Minnesota, USA, 1999.

Ilhan, S., Demirel, R., Asan, A., Bayçu, G., Kınacı, E., Colonial and Morphological Characteristics of Some Microfungal Species Isolated from Agricultural Soils in Eskişehir Province (Turkey), 30: 95-104 (2006).

Jobard, M., Rasconi, S., Sime-Ngando, T., Fluorescence in Situ Hybridization of Uncultured Zoosporic Fungi: Testing with Clone-FISH and Application to Freshwater Samples using CARD-FISH, Journal of Microbiological Methods, 83: 236-243 (2010).

Kantarcıoğlu, A. S., Yücel, A., Aspergillus Cinsi Mantarlar ve Invaziv Aspergilloz: Mikoloji, Patogenez, Laboratuvar Tanımı, Antifungallere Direnç ve Duyarlılık Deneyleri, Cerrahpaşa Tıp Dergisi, 34(3): 140-145 (2003).

Kasapgil İnce, B., Usenti, I., Eyigor, A., Ayman Oz, N., Kolukirik, M., Ince, O., Analysis of Methanogenic Archaeal and Sulphate Reducing Bacterial Populations in Deep Sediments of the Black Sea, Geomicrobiology Journal, 23: 285-292 (2006).

Klich, M.A., Identification of common Aspergillus species, Centraalbureau voor Schimmelcultures, Utrecht, Netherlands, (2002).

Li, S., Spear, R.N., Andrews, J.H., Quantitative Fluorescence in Situ Hybridization of Aureobasidium pullulans on Microscope Slides and Leaf Surfaces, Applied and Cooling tower Microbiology, 63(8): 3261-3267 (1997).

Lischewsk, A., Amann, R.I., Harmsen, D., Merkert, H., Hacker, J., Morschhauser, J., Specific Detection of Candida albicans and Candida tropicalis by Fluorescent in Situ Hybridization with an 18S rRNA-Targeted Oligonucleotide Probe, Microbiology, 142: 2731-2740 (1996).

Moter, A., Göbel, U.B., Fluorescence in Situ Hybridization (FISH) for Direct Visualization of Microorganisms, Journal of Microbiological Methods, 41: 85-112 (2000).

Öner, M., Mikoloji I, Myxomycetes, Phycomycetes, Ascomycetes, 4. Baskı. Ege Üniversitesi Fen Fakültesi Kitaplar Serisi no 53. Ege Üniversitesi Basımevi, Bornova, İzmir. (1998).

Sime, A.D., Abbott, L.L., Abbott, S.P., Mounting Medium for Use in Indoor Air Quality Spore-Trap Analyses, Mycologia., 94: 1087-1088 (2002).

Spear, R.N., Li, S., Nordheim, E.V., Andrews, J.H., Quantitative Imaging and Statistical Analysis of Fluorescence Hybridization (FISH) of Aureobasidium pullulans, Journal of Microbiological Methods 35: 101-110 (1999).

Szymanska, J., Evaluation of Mycological Contamination of Dental Unit Waterlines, Annals of Agricultural and Cooling tower Medicine,12:153-155 (2005).

Yazıcıoğlu, M., Asan, A., Ones, U., Vatansever, U., Şen, B., Ture, M., Bostancıoğlu, M., Pala, O.: Indoor Airborne Fungal Spores and Home Characteristics in Asthmatic Children from Edirne Region of Turkey, Allergologia et Immunopathologia, 32(4): 197-203 (2004). 